\title{
Obituary: A Remembrance of George E. Omer Jr. MD (1922-2014)
}

\author{
Anthony Calabro MA
}

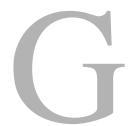

eorge E. Omer Jr. MD, an emeritus member of The Association of Bone and Joint Surgeons ${ }^{\circledR}$, passed away on Thursday, November 20, 2014, in Spring, TX, USA at the age of 92 .

An internationally renowned hand surgeon, Dr. Omer (Fig. 1) played an instrumental role in establishing a certificate of added qualification for hand surgery. It was his early advocacy that helped "legitimize the pathway" for graduates to become specialized in hand surgery [3].

"That's his legacy," Moheb S. Moneim MD, Professor and Chair Emeritus of the Department of Orthopaedics \& Rehabilitation at the University

The author certifies that his, or any members of his immediate family, has no commercial associations (eg, consultancies, stock ownership, equity interest, patent/licensing arrangements, etc) that might pose a conflict of interest in connection with the submitted article.

The opinions expressed are those of the writers, and do not reflect the opinion or policy of $C O R R^{\mathbb{R}}$ or The Association of Bone and Joint Surgeons ${ }^{\circledR}$.

\section{A. Calabro MA ( $\square)$}

Clinical Orthopaedics and Related

Research $\AA, 1600$ Spruce Street,

Philadelphia, PA 19013, USA

e-mail: acalabro@clinorthop.org of Mexico School of Medicine said in a phone interview with $C O R R^{\circledR}$. "He recognized early that there needed to be formal credentialing for hand surgeons."

Born in Kansas City, KS, USA in 1922, Dr. Omer enrolled in the University of Kansas School of Medicine after completing his undergraduate degree in 1944. After his first year of medical school, he enlisted in the US Army. He returned to medical school in 1950, earning his degree.

Dr. Omer's military career spanned three major wars. He served as a surgical technician in World War II, as a physician in the Korean War, and as the Director of the Orthopaedic Residency Training Program at Walter Reed Army Medical Center during the Vietnam War. Along the way, he was assigned to Fort Benning Hospital in Georgia, USA, Brooke Army Medical Center in San Antonio, TX, USA, and Fitzsimons Army Medical Center in Denver, CO, USA, where he was the Chief of the Hand Surgery Unit [3].

By the time he retired from service as a colonel in 1970, Dr. Omer was one of the US Army's most prominent surgeons.

"He was a superb hand surgeon-a strategic thinker and planner, an amazing academician," Robert Schenck MD, Chair of the Department of Orthopaedics \& Rehabilitation at the University of
New Mexico School of Medicine (UNM School of Medicine) told $\operatorname{CORR}^{\circledR}$ in a phone interview.

When Dr. Omer arrived at UNM School of Medicine in 1970, the orthopaedics program was housed within a small division of the department of surgery [3]. He insisted on the orthopaedics division becoming its own department. This was a unique move at the time for a teaching school like the UNM School of Medicine, and perhaps only a man of Dr. Omer's vision, discipline, and experience could handle such a giant task.

"You need resources in order to build a department, and George was a master of acquiring the necessary resources for his department." Dr. Moneim said.

In time, Dr. Omer would establish an organized division of hand surgery, a program in physical and occupational therapy, and a microsurgery service with Dr. Moneim.

"With all due respect to those who came before him, and there some really great people that came before him, George Omer is the father of the Department of Orthopaedics \& Rehabilitation at UNM School of Medicine," Dr. Schenck MD said.

While building and establishing the orthopaedics and rehabilitation department, Dr. Omer also served key leadership roles in medical societies, 


\section{Obituary}

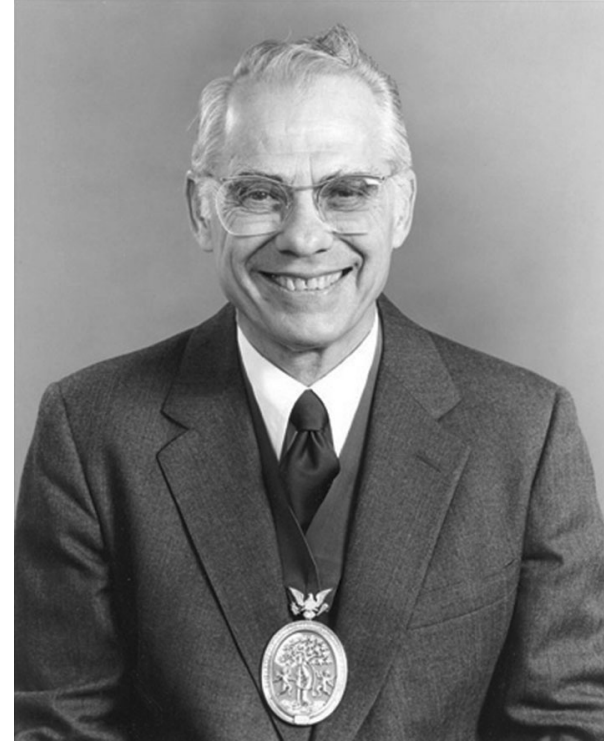

Fig. 1 Dr. Omer was instrumental in establishing a certificate of added qualification for hand surgery. (Published with permission from the University of New Mexico School of Medicine).

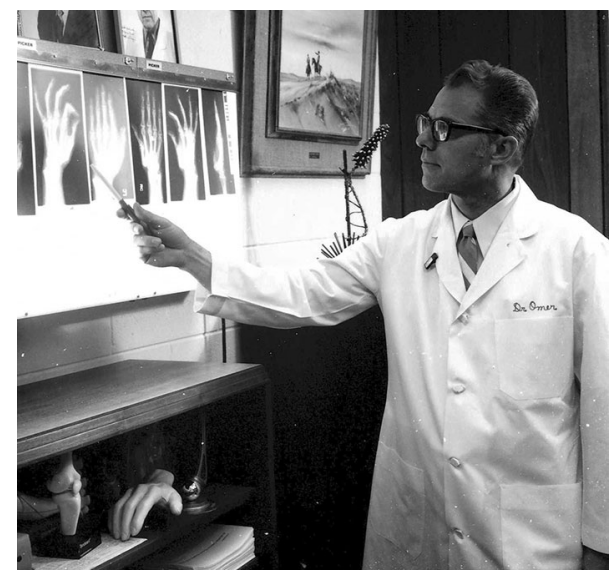

Fig. 2 According to his colleague Dr. Moneim, hand surgery was Dr. Omer's number one passion. (Published with permission from the University of New Mexico School of Medicine). including becoming President of both The American Society for Surgery of the Hand in 1978-1979 and the American Orthopaedic Association in 1989. He wrote numerous papers in various publications including $\operatorname{CORR}^{\circledR}[1]$ and coauthored a book on the management of peripheral nerve problems, a classic, comprehensive, and highly-cited work [2, 3].

In 1990, Dr. Omer retired as the Chairman and Chief of UNM School of Medicine medical departments, assuming the role of Professor and Chairman Emeritus. Upon his retirement, the department had grown to 17 full-time faculty members, included a residency program, and offered specialties in hand, sports, and trauma [3].

Following his retirement, Dr. Omer remained active both in his community, and in hand surgery.

"George's number one passion was hand surgery," Dr. Moneim said. "He never played golf or anything like that. Even during his retirement, he could talk about hand surgery for hours and hours" (Fig. 2).

Dr. Omer was preceded in death by his older son, Eric, and is survived by his wife, Wendie, his sister Betty Creek, his son Michael and daughterin-law Marla. He is also survived by his grandchildren Adria, Miranda, Tera, Cody, Macy, and Greg as well as by his nephews and niece Doug and Jon Vilven, Robert (Bob) and David Creek, Sharyn Holt, and their spouses. 


\section{Obituary}

\section{References}

1. Omer GE Jr. The development of orthopedic certification in the United States. Clin Orthop Relat Res. 1990;257:11-17.
2. Omer GE, Spinner M, Van Beek AL. Management of Peripheral Nerve Problems. $2^{\text {nd }}$ ed. Philadelphia, PA: W. B. Saunders; 1998.
3. UNM School of Medicine Department of Orthopaedics \& Rehabilitation. Our founding physician. Available at: http://orthopaedics.unm.edu/about-us/ omer.html. Accessed February 9, 2016. 